(2) Open Access Full Text Article

ORIGINAL RESEARCH

\title{
Controlled release of TGF-beta I from RADA self-assembling peptide hydrogel scaffolds
}

This article was published in the following Dove Press journal:

Drug Design, Development and Therapy

22 September 2016

Number of times this article has been viewed

\author{
Ao Zhou' \\ Shuo Chen ${ }^{1,2}$ \\ Bin $\mathrm{He}^{\prime}$ \\ Weikang Zhao' \\ Xiaojun Chen' \\ Dianming Jiang' \\ 'Department of Orthopedics, The \\ First Affiliated Hospital of Chongqing \\ Medical University, Chongqing, \\ ${ }^{2}$ Department of Orthopedics, \\ Dujiangyan Medical Center, \\ Dujiangyan, People's Republic of China
}

Correspondence: Dianming Jiang Department of Orthopedics, The First Affiliated Hospital of Chongqing Medical University, No I Yi Xue Yuan Road, Yuzhong District, Chongqing 4000I6, People's Republic of China Tel/fax +8623890I I212 Emailjdm571026@vip.163.com

\begin{abstract}
Bioactive mediators, cytokines, and chemokines have an important role in regulating and optimizing the synergistic action of materials, cells, and cellular microenvironments for tissue engineering. RADA self-assembling peptide hydrogels have been proved to have an excellent ability to promote cell proliferation, wound healing, tissue repair, and drug delivery. Here, we report that D-RADA16 and L-RADA16-RGD self-assembling peptides can form stable second structure and hydrogel scaffolds, affording the slow release of growth factor (transforming growth factor cytokine-beta 1 [TGF-beta 1]). In vitro tests demonstrated that the plateau release amount can be obtained till 72 hours. Moreover, L-RADA16, D-RADA16, and L-RADA16RGD self-assembling peptide hydrogels containing TGF-beta 1 were used for 3D cell culture of bone mesenchymal stem cells of rats for 2 weeks. The results revealed that these three RADA16 peptide hydrogels had a significantly favorable influence on proliferation of bone mesenchymal stem cells and hold some promise in slow and sustained release of growth factor.
\end{abstract}

Keywords: molecular self-assembly, self-assembling peptide, hydrogel scaffolds, controlled release, TGF-beta 1, bone mesenchymal stem cells

\section{Introduction}

Ideal hydrogel scaffolds consisting of natural or synthetic materials are important for regenerative medicine and tissue engineering. Materials such as alginate, agarose, and collagen have been widely applied in medical and drug research. However, there are some problems such as poor biocompatibility, immune rejection, and degradation product toxicity. Therefore, it is crucial and urgent to develop a novel and ideal biomaterial hydrogel. ${ }^{1-3}$

Recent studies have shown that self-assembling peptide nanofiber hydrogel scaffolds have been found to exert a significantly favorable influence on bone and cartilage regeneration, wound healing, as well as drug delivery. ${ }^{1-5}$ These ionic self-complementary peptides can spontaneously self-assemble into beta sheet secondary structure and peptide nanofiber after stimulation with electrolyte solutions. In addition, these peptide nanofibers with a diameter of 10-20 $\mathrm{nm}$ can then form highly hydrous hydrogels with pore sizes ranging from $5 \mathrm{~nm}$ to $200 \mathrm{~nm}$ and water content $>99.5 \% \mathrm{w} / \mathrm{v}$. $^{6-10}$ Self-assembling peptide hydrogels have been proved to have good biocompatibility, and they can completely degrade without any toxicity of degradation products. , $^{9,11,12}$ They also have the ability to deliver signal molecules and functional proteins. ${ }^{13-15}$ For example, RADA16 peptide hydrogel scaffolds afforded the controlled release of various functional proteins, including fibroblast growth factor, vascular endothelial growth factor, brain-derived neurotrophic factor, lysozyme, trypsin inhibitor, BSA, and IgG. Further studies have demonstrated that these released functional proteins can maintain their original protein structure and function based on conformation analysis 
and bioactivity detection. ${ }^{9,14}$ Many studies have demonstrated that self-assembling peptide hydrogel scaffolds have been widely applied for drug and protein delivery, tissue regeneration, and cell culture. ${ }^{1-5,9}$

Previous studies have demonstrated that L-RADA16 peptide hydrogels can mimic cell microenvironment and promote cell proliferation, whereas D-form peptide hydrogels have the ability to induce cell growth and rapid hemostasis. ${ }^{10,16}$ In addition, peptide hydrogels could be functionalized with active motifs such as IKVAV and RGD, which benefited to regulate cell behaviors, including differentiation, attachment, and migration. ${ }^{17,18}$ This study focused on the secondary structure of D-RADA16 peptide and D-RADA16-RGD peptide hydrogel scaffold using circular dichroism spectroscopy, their microstructural feature using transmission electron microscopy (TEM) and rheometry assays, as well as the capability of promoting the proliferation of bone mesenchymal stem cells (BMSC) of rats compared with L-RADA16 peptide hydrogel scaffolds. It was known that transforming growth factor beta 1 (TGF-beta 1) cytokine can promote osteogenesis and chondrogenesis and can be used for cell function assays or blood vessel regeneration. ${ }^{19-21}$ Peptide hydrogel scaffolds containing TGF-beta 1 were used to explore their potential in controlled release of TGF-beta 1 for the functions of BMSC.

\section{Materials and methods}

\section{Peptide synthesis and purification}

D-RADA16 peptide sequence is Ac-RADARADARADA RADA-CONH 2 (containing all D-amino acids). L-RADA16 sequence containing all L-amino acids is Ac-RADAR ADARADARADA-CONH ${ }_{2}$, and L-RADA16-RGD sequence containing all L-amino acids is Ac-RADAR ADARADARADARGDS-CONH${ }_{2}$. These peptides were commercially custom-synthesized by solid-phase peptide synthesis (Shanghai Biotech Bioscience and Technology Co, Ltd, Shanghai, People's Republic of China). The N-terminus and C-terminus of these peptides were acetylated and amidated, respectively, and the peptides were purified by high-performance liquid chromatography and characterized by mass spectroscopy. The final purity of the D-RADA16, L-RADA16, and L-RADA16-RGD was $97.78 \%, 97.45 \%$, and $96.68 \%$, respectively.

\section{Circular dichroism spectroscopy}

The sample was composed of RADA peptide $(20 \mathrm{mg} / \mathrm{mL})$ dissolved in $\mathrm{NaCl}$ solution, and the concentration was regulated to $50 \mu \mathrm{M}$. The sample was prepared at $25^{\circ} \mathrm{C}$ and equilibrated for 30 seconds. A total of $500 \mu \mathrm{L}$ of sample solution was added in a circular dichroism colorimetric cuvette. Tests were conducted using a J-810 CD spectrometer (J-810;
JASCO Corporation, Tokyo, Japan). We measured the entire 190-310 nm wavelength range, and the wavelength ranging from 190 to $260 \mathrm{~nm}$ was used for the analysis.

\section{Transmission electron microscopy}

TEM peptide solution samples $(5 \mathrm{mg} / \mathrm{mL})$ were prepared at $25^{\circ} \mathrm{C}$ by dissolving lyophilized peptide powder in phosphatebuffered saline (PBS, pH 7.4). After 48 hours, a micropipette was used to load $5 \mathrm{~mL}$ of this peptide solution to a carboncoated copper grid. The excess solution was removed by a piece of filter paper. Then, the peptide solution sample was dyed using $10 \mathrm{~mL}$ of uranyl acetate for 30 seconds and dried overnight in a desiccator, and then bright-field images were taken using a transmission electron microscope (Philips Tecnai G2 F20, Koninklijke Philips N.V., Amsterdam, the Netherlands) operating at $200 \mathrm{kV}$.

\section{Rheometry}

Rheology assays were carried out using a $1^{\circ}$ stainless steel cone-controlled rheometer with a diameter of $20 \mathrm{~mm}$ (Thermo Fisher Scientific, Waltham, MA, USA). Samples were dissolved in PBS (pH 7.4) at a concentration of $10.0 \mathrm{mg} / \mathrm{mL}$. The peptide solution was mixed with PBS ( $\mathrm{pH} 7.4)$ at a volume ratio of $1: 1$ or $1: 3$ and stored at $4^{\circ} \mathrm{C}$ in a refrigerator over night, and $150-200 \mu \mathrm{L}$ of samples were used for analysis at $25^{\circ} \mathrm{C}$.

\section{Cell culture}

The BMSC were obtained from the femurs of 4-5 weeks old female Sprague Dawley rats from the experimental animal center of Chongqing Medical University. Conventional reagents were used, and cells prepared for $2 \mathrm{D}$ cell culture and a modified 3D culture were grown in $10 \%$ fetal bovine serum (PAN Biotech UK Ltd., Dorset, UK). All cells were subcultured to third to fifth generation for follow-up experiments. Our study followed the principles of Medical Ethics and Declaration of Helsinki, and judged by the Ethics Committee of the First Affiliated Hospital of Chongqing Medical University. This experimental protocol was approved by the Institutional Animal Care and Use Committee of Chongqing Medical University of China, and Chinese national guidelines for the care and use of laboratory animals were applied.

\section{TGF-beta I release}

RADA self-assembling peptide hydrogels with or without BMSC were used to release TGF-beta 1 at $37^{\circ} \mathrm{C}$. The TGF-beta 1 solution was mixed with $1 \% \mathrm{v} / \mathrm{w}$ RADA selfassembling peptide solutions $(20 \mathrm{mg} / \mathrm{mL})$, and the final mixed peptide solution consisted of $10 \mathrm{ng}$ of TGF-beta 1 and $40 \mu \mathrm{L}$ of peptide solution. A total of $20 \mu \mathrm{L}$ of mixed solution was added 
into a 24-multiwell plate (NEST Biotechnology Co. Ltd., Rahway, NJ, USA) and then was stimulated to self-assemble after adding $180 \mu \mathrm{L}$ of PBS $(7.4 \mathrm{pH})$ in each well for at least 30 minutes. Empty wells filled with PBS were used as the control group. BMSC of adult Sprague Dawley rat were cultured in the 24-multiwell plate, and the concentration was $2 \times 10^{4}$ cells per well. Standard DMEM/F12 culture medium without growth factors was used for the test, and the dose was $500 \mu \mathrm{L}$ per well. Cell proliferation was assessed in 3 days, 7 days, and 14 days using a VersaMax microplate reader. Enzyme-linked immunosorbent assay (ELISA) kit (eBioscience, San Diego, CA, USA) was used to measure the amount of TGF. A total of $40 \mu \mathrm{L}$ of supernatant of the mixed solution in each well was taken away at the time point of 1 hour, 2 hours, 4 hours, 8 hours, 24 hours, 72 hours, and 168 hours, while the same dose of fresh PBS solution was added into each well slowly and gently. These supernatant samples were stored in $\mathrm{a}-80^{\circ} \mathrm{C}$ refrigerator for the following ELISA determination. The amounts of TGF-beta 1 in each group were then obtained and the diffusion coefficients were calculated according to the 1-D unsteady state form of Fick's second law. ${ }^{9,22}$

\section{Cell imaging and proliferation assay}

We observed cells through an inverted microscope (Olympus Corporation, Tokyo, Japan) after coculturing for 2 weeks. CCK-8 assay was applied to investigate the effect of TGFbeta 1 released from RADA peptide hydrogel scaffolds on cell viability. CCK-8 kit (Dojindo Laboratories, Kumamoto, Japan) was added into the culture medium of wells in the ratio of 1:10, and then the 24-multiwell plate was incubated at $37^{\circ} \mathrm{C}$ for 1 hour. The absorbance was measured using a VersaMax microplate reader (Thermo Fisher Scientific) at an absorption wavelength of $450 \mathrm{~nm}$. Data were expressed as arbitrary absorbance units.

\section{Statistical analysis}

SPSS software was used for statistical analysis. An unpaired $t$-test was used to compare the two groups. Comparisons between multiple groups were performed by one-way analysis of variance followed by least significant difference or Student-Newman-Keuls as post hoc tests. Data were expressed as mean \pm standard error of the mean, and a $P$-value of $<0.05$ was defined as statistically significant.

\section{Results}

\section{Secondary structure of L-RADA I6-RGD}

The $\beta$-sheet structure of L-RADA16-RGD is shown in Figure 1, indicating that L-RADA16-RGD peptide could

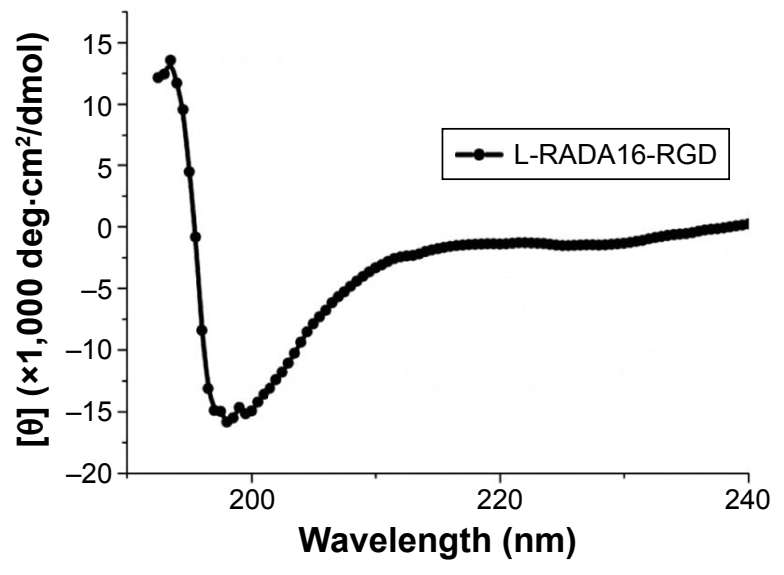

Figure I Circular dichroism spectra of the chiral peptides. Notes: Peptide L-RADA I6-RGD of $50 \mu \mathrm{M}$ has stable secondary structures in $20 \mathrm{mM}$ $\mathrm{NaCl}$ at $25^{\circ} \mathrm{C}, 193.5 \mathrm{~nm}$ (13.5827), $193 \mathrm{~nm}$ (12.4508), and $198 \mathrm{~nm}$ (-I5.8484). Abbreviation: deg, degree.

produce stable secondary structures in $20 \mathrm{mM} \mathrm{NaCl}$ at $25^{\circ} \mathrm{C}$. This result indicates that the $3 \mathrm{D}$ cell culture should be handled quickly at room temperature.

\section{Nanostructures of RADAI 6 self- assembling peptide nanofiber scaffolds}

TEM was applied to observe the microstructure of the RADA16 peptide hydrogels. TEM images showed that the RADA16 peptides were able to self-assemble into interwoven nanofibers at $25^{\circ} \mathrm{C}$ (Figure 2). These nanofibers were $\sim 10 \mathrm{~nm}$ in diameter and formed pores $<200 \mathrm{~nm}$, whereas the diameter of nanofibers of L-RADA16-RGD was wider than that of the other peptides. The physical network and these structures coincided with the mechanism of interwoven formation in these peptide hydrogels.

\section{Rheological tests of L-RADAI6 and D-RADAI 6}

These peptides can self-assemble into nanofibers and further hydrogelation occurs. The earliest few minutes of hydrogelation are crucial to keep cells in the truly 3D microenvironment. However, gelation nanomechanical properties in the cell media are poorly clear, especially in the initial phase. We chose typical ions $\left(\mathrm{Na}^{+} / \mathrm{K}^{+}\right)$in the cell media to investigate the gelation nanomechanical properties. Rheological experiments measure a storage modulus $\left(G^{\prime}\right)$ and a loss modulus $\left(G^{\prime \prime}\right)$ by evaluating elastic response (rigidity) and viscous response of material, respectively, by varying frequencies of applied oscillatory stress. Upon comparing the rheological property of D-RADA16 and L-RADA16 $(1 \mathrm{mg} / \mathrm{mL})$ self-assembly in water or salt solution $(0.01 \mathrm{M}$ PBS, $\mathrm{Na}^{+} / \mathrm{K}^{+}$), D-RADA16 peptide is more sensitive to 

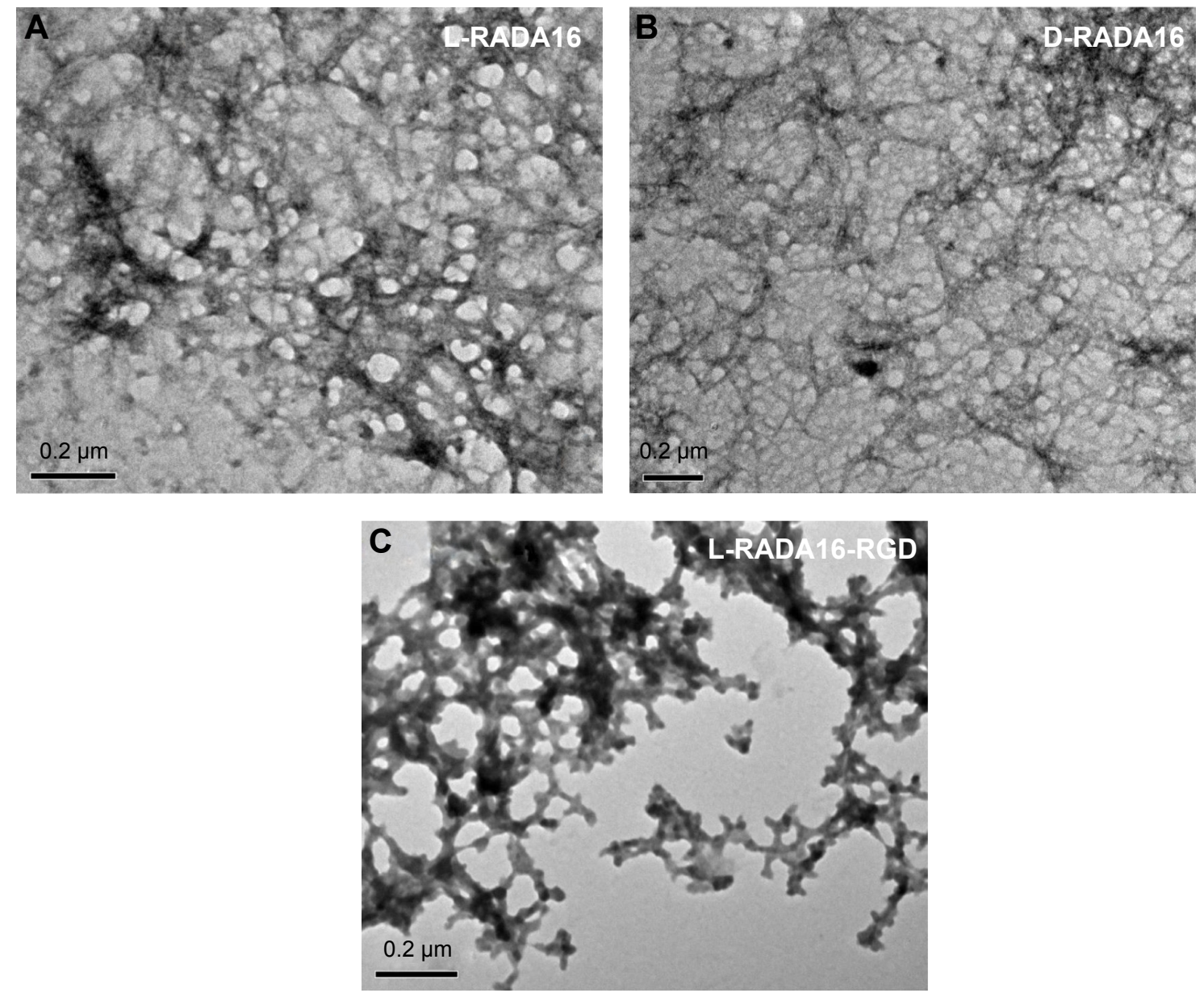

Figure 2 TEM images of microstructure of (A) L-RADA I6, (B) D-RADAI6, and (C) L-RADAI6-RGD (200 nm).

Note: Magnification: $(A) \times 75,000$; (B) $\times 60,000$; and (C) $\times 75,000$.

Abbreviation: TEM, transmission electron microscopy.

ions than L-RADA16, and the frequency $G^{\prime}$ was greater than $G^{\prime \prime}$ (Figure 3A). High concentration of peptides was revealed to result in higher frequency $G^{\prime}(20.0 \mathrm{mg} / \mathrm{mL})$, both D- and L-RADA $16>12 \mathrm{~Pa}$ (Figure $3 \mathrm{~A}$ and $\mathrm{B}$ ), and D-form peptide showed a little bit lower frequency $G^{\prime}$ (Figure 3B). High concentration of D-RADA16 and L-RADA16 demonstrated similar mechanical properties and $\mathrm{Na}^{+} / \mathrm{K}^{+}$can affect them immediately. A reasonable explanation is that
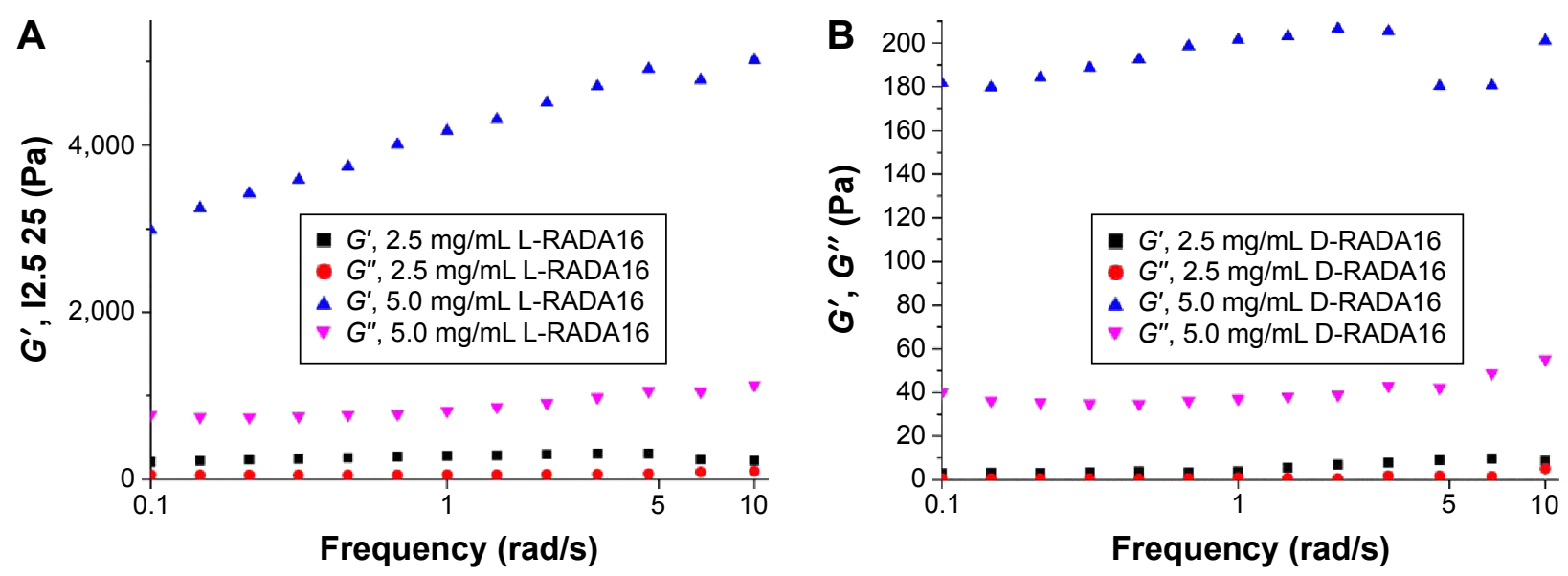

Figure 3 Rheological assays: $2.5,5.0 \mathrm{mg} / \mathrm{mL}$ peptide hydrogels in PBS (pH 7.4), $25^{\circ} \mathrm{C}$.

Notes: (A) The rheological properties of 2.5 and $5.0 \mathrm{mg} / \mathrm{mL}$ L-RADA 16 hydrogels in $10.0 \mathrm{mg} / \mathrm{mL} \mathrm{PBS} \mathrm{(pH} 7.4$ ) at $25^{\circ} \mathrm{C}$. (B) The rheological properties of 2.5 and $5.0 \mathrm{mg} /$ $\mathrm{mL}$ D-RADA 6 hydrogels in $10.0 \mathrm{mg} / \mathrm{mL}$ PBS $(\mathrm{pH} 7.4)$ at $25^{\circ} \mathrm{C}$.

Abbreviation: PBS, phosphate-buffered saline. 
$\mathrm{Na}^{+} / \mathrm{K}^{+}$can induce the peptides to self-assemble into short nanofibers rapidly. Our result is useful in a process of $3 \mathrm{D}$ cell culture.

\section{In vitro TGF-beta I release from three types of RADAI 6 hydrogels}

The release experiments were observed for 14 days. The release profiles of TGF-beta 1 from the RADA peptide hydrogels are shown in Figures 4 and 5 . Results revealed that $~ 18 \%$ (Figure 4) and 31\% (Figure 5) of incorporated TGF were released from $1 \% \mathrm{w} / \mathrm{v}$ L-RADA16-RGD hydrogel within the first 24 hours. In contrast, only 17\% (Figure 4) and 20\% (Figure 5) of TGF-beta 1 were released from the D-RADA16 hydrogel within 24 hours. These results demonstrated that protein release rate in different types of peptide hydrogel was dissimilar. Compared with the D-RADA16 hydrogel, the initial burst effect of the L-RADA16-RGD hydrogel was higher.

\section{Released TGF-beta I activity assays}

TGF-beta 1 has been proven to have the ability to stimulate and promote proliferation of BMSC by adjusting mitotic process. To assess the activity of the TGF-beta 1 released from the RADA peptide hydrogel scaffolds CCK- 8 assay was used (Figure 6), which indicated that there was enhanced proliferation of BMSC on L-RADA16, D-RADA16, and L-RADA16-RGD scaffolds, especially on L-RADA16 scaffolds incorporating TGF-beta 1 , whereas the proliferation of BMSC cultured on RADA16 scaffolds was not significantly different from the control group. Collectively, asymptotical delivery of TGF-beta 1 from these peptide scaffolds was shown within the first 8 hours, and after that initial burst

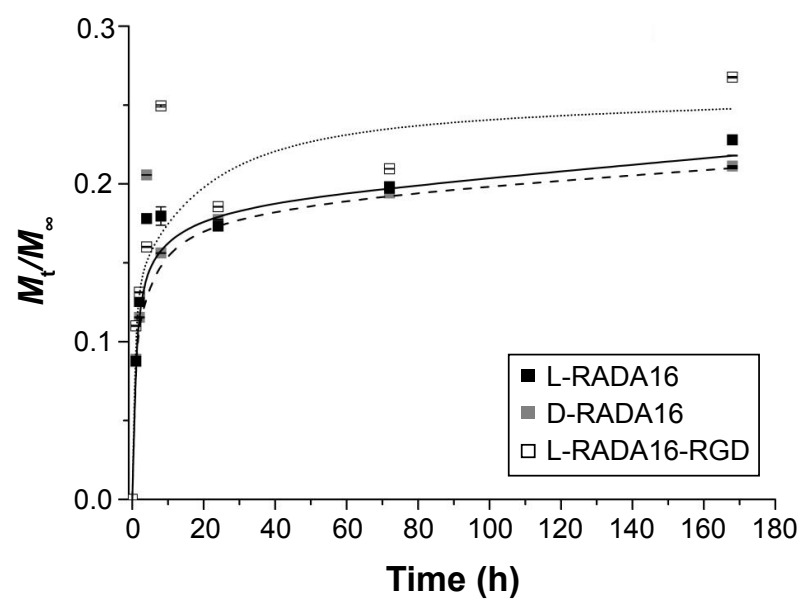

Figure 4 Release profiles for TGF-beta I through three types of self-assembling peptide hydrogels (data points represent the average of three samples).

Abbreviations: h, hours; TGF, transforming growth factor.

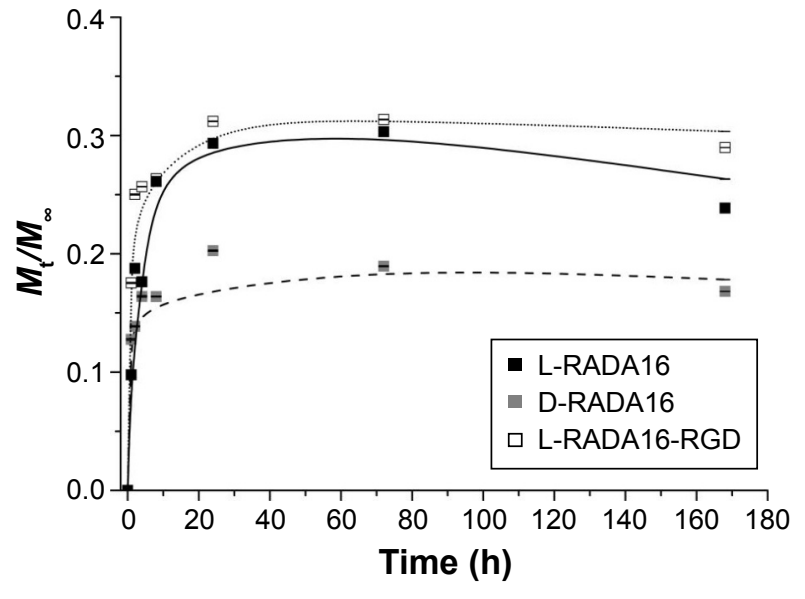

Figure 5 Release profiles for TGF-beta I through three types of self-assembling peptide hydrogels 3D cells coculture (data points represent the average of three samples). Abbreviations: h, hours; TGF, transforming growth factor; 3D, three-dimensional.

and similar release continued for the next days on condition that the whole release systems should not be disturbed and the diffused and released TGF-beta 1 should be kept in balance. The initial burst release might also be affected by the covered TGF-beta 1 on the surface peptide scaffolds. This result suggested that the release effect of active TGFbeta 1 was possibly able to continue for at least 2 weeks till the storage of the diffused growth factor was exhausted, and the electrostatic charges in the self-assembling nanofibers may interact with the TGF. These findings may be helpful for tissue regeneration strategies with sustained release of TGF-beta 1 to stimulate and promote the chondrogenesis or osteogenesis.

\section{Discussion}

\section{Physicochemical properties of self- assembling peptide nanofiber hydrogel}

Self-assembling peptide nanofiber hydrogel provides the possibility of slow and sustained release of growth factors mainly due to its stable network structures. Circular dichroism spectroscopy image showed that L-RADA16RGD had stable $\beta$-sheet structure in $\mathrm{NaCl}$ solution at $25^{\circ} \mathrm{C}$ (Figure 1). But the secondary structure of this peptide can be affected by high temperature. CD spectrum also showed the L-RADA 16 and D-RADA 16 had a stable $\beta$-sheet secondary structure at $4{ }^{\circ} \mathrm{C}$. The change in the secondary structure of D-RADA16 after the stimulation of PBS is much stronger than L-RADA16 suggesting that D-RADA16 is more easily affected by ions than L-RADA16 (unpublished data). Rheometry assays showed that L-RADA16 and D-RADA16 nanofiber hydrogels $(5.0 \mathrm{mg} / \mathrm{mL})$ had stable mechanical features. The increase in concentration can improve the stability of hydrogels. 

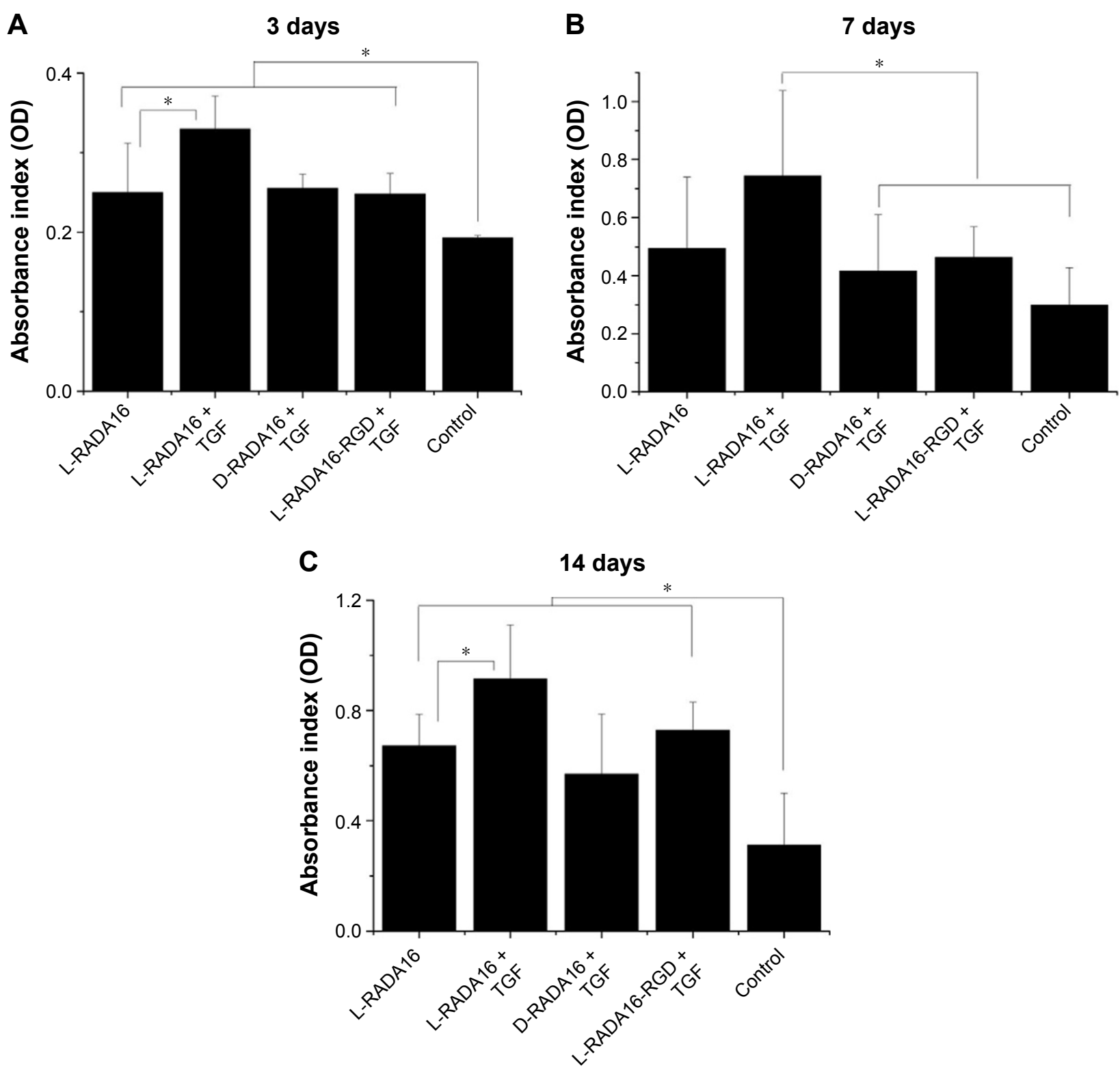

Figure 6 Proliferation effect of released TGF-beta I over bone mesenchymal stem cells.

Notes: The cells and RADAI6 hydrogels contained TGF were co-cultured for 3 days (A), 7 days (B), and I4 days (C). CCK-8 assay for proliferated progeny ( $\mathrm{n}=5$ ). In the case of L-RADA I6, a long-term effect of released TGF-beta I is evidenced by significantly higher total cell population. The TGF-beta I mitogenic activity can be appreciated till 2 weeks after being mixed with the self-assembling scaffolds. $* P<0.05$.

Abbreviations: TGF, transforming growth factor; OD, optical density.

\section{Growth factor release through the self- assembling peptide hydrogel}

It is critical to apply biomaterials for regulating cellular microenvironment and tissue regeneration. ${ }^{1,2,23}$ RADA selfassembling peptide nanofiber hydrogels formed 3D pores with diameter similar to spherical protein and provided an ideal network structure for cell growth. They also provided a natural physical barrier for controlled release of functional proteins. Figure 2 shows that the nanofiber and pore size of D-RADA16 hydrogel was smaller than that of L-RADA16 and L-RADA16-RGD, which may account for the slow release rate of TGF-beta 1 from D-RADA16 hydrogel than other hydrogels (Figures 4 and 5). However, the secondary structure of D-RADA16 was found to be more easily affected by high temperature and ions. ${ }^{24,25}$ An initial burst of TGF-beta 1 that occurred in the first 8 hours maybe due to the surface location of protein molecules (Figures 4 and 5). Molecular motion might exist in the highly interwoven nanofiber network of the hydrogel. ${ }^{9,14,22}$ In addition, the release rate of TGF-beta 1 from the peptide hydrogel $(1 \% \mathrm{w} / \mathrm{v})$ was slowed down for 24 hours, after that a plateau value occurred asymptotically. However, a $100 \%$ molecule release is seldom observed in the hydrogels. Protein molecules in the interwoven nanofiber network structure of the hydrogel scaffold are physically obstructed and held 
back and most diffusate cannot move freely, which might be the cause for that. ${ }^{7,26}$ Besides, our study also demonstrated that RADA16 self-assembling peptide would not affect the activity of TGF-beta 1 in cell proliferation.

\section{Cell proliferation}

Self-assembling peptide hydrogels are composed of amino acids, which have the function of biological recognition and good compatibility. RADA16 self-assembling peptide hydrogel can highly simulate the extracellular matrix and form suitable microenvironment for cell growth and functional protein action. During the release process, protein structure and bioactivity are maintained. TGF-beta 1 can promote the proliferation of mesenchymal stem cells..$^{19,20}$ In Figure 6, all experiment groups had better cell proliferation than the control group. Besides, cell proliferation on the L-RADA16 + TGF-beta 1 group was significantly better than that on the L-RADA16 group, indicating the promotion of released TGF-beta 1 to proliferation of mesenchymal stem cells. In Figures 4 and 5 , the release rate and release amount of TGF-beta 1 of L-RADA16 + TGF-beta 1 group were higher compared with those of the D-RADA16 + TGF-beta 1 group on 7 days. Previous studies showed that $\mathrm{D}$-form self-assembling peptide hydrogels had the ability of being resistant to natural proteases degradation and promoting cell proliferation, which were beneficial to tissue regeneration and repair. ${ }^{10,27}$ The L-RADA16 + TGF-beta 1 group also showed a better effect on cell proliferation than that in the L-RADA16-RGD + TGFbeta 1 group. But the effect of L-RADA16-RGD on promoting cell differentiation, migration, and adhesion is greater than that of L-RADA16. ${ }^{28-32}$ These results indicated that the sustained release of TGF-beta 1 from L-RADA16 hydrogel had better promotion to cell proliferation than L-RADA16RGD hydrogel, which was consistent with the release profiles of TGF-beta 1 from peptide hydrogel. In Figure 7, compared with the control group, BMSC in RADA16 peptide
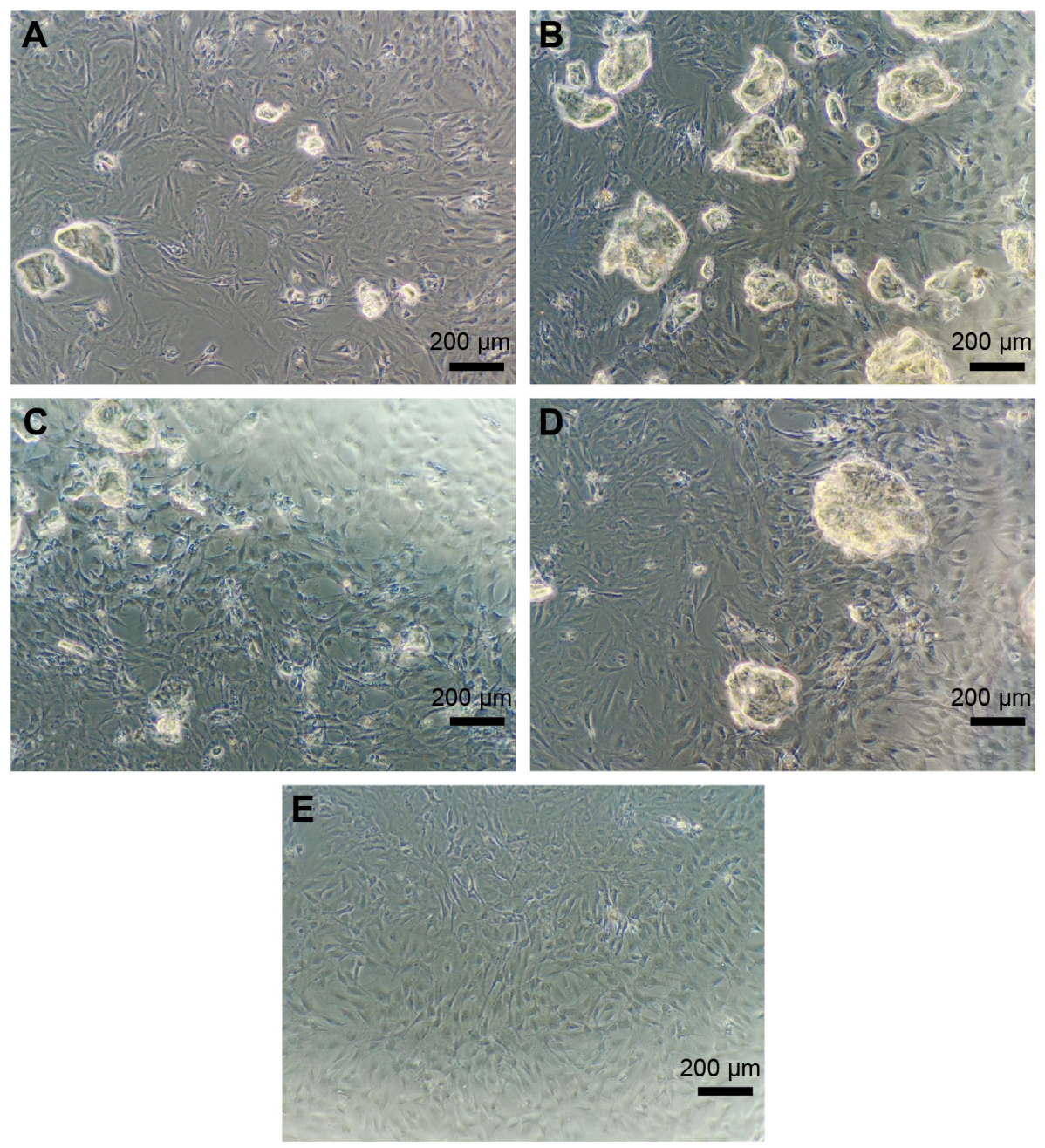

Figure 7 The morphological results of BMSC in each group under a light microscope $(\times 100)$.

Notes: (A) L-RADAI6 group, (B) L-RADAI6 + TGF-beta I group, (C) D-RADAI6 + TGF-beta I group, (D) L-RADAI6-RGD + TGF-beta I group, and (E) negative control. Abbreviations: BMSC, bone mesenchymal stem cells; TGF, transforming growth factor. 
hydrogel showed no obvious change in morphology, cell apoptosis, and degenerescence, which also demonstrated that the RADA16 peptide hydrogels were atoxic and safe for cells. Thus, RADA16 hydrogel can be used as an ideal tissue engineering material for the regeneration and repair of tissues or organs.

\section{Conclusion}

Our studies focused on controlled release of TGF-beta 1 from RADA16 functional self-assembling peptide hydrogels as well as the promotion to cell proliferation. With $3 \mathrm{D}$ cell culture to the microenvironment formed by peptide hydrogels, there was a significant difference in high cell viability and low-level cell apoptosis between the L-form self-assembling peptide and D-form peptide scaffolds. This study using two chiral self-assembling peptides and functional motifs benefited to stimulate and promote the development of new biomaterials for tissue engineering at amino acids level and may further enhance the application of designer self-assembling peptides in clinical medicine and nanomedicine.

\section{Acknowledgment}

This work was supported by the National Natural Science Foundation of China (NSFC, 81472057).

\section{Disclosure}

The authors report no conflicts of interest in this work.

\section{References}

1. Mano JF, Silva GA, Azevedo HS, et al. Natural origin biodegradable systems in tissue engineering and regenerative medicine: present status and some moving trends. $J R$ Soc Interface. 2007;4(17):999-1030.

2. Hunt NC, Grover LM. Cell encapsulation using biopolymer gels for regenerative medicine. Biotechnol Lett. 2010;32(6):733-742.

3. Worthington P, Pochan DJ, Langhans SA. Peptide hydrogels-versatile matrices for 3D cell culture in cancer medicine. Front Oncol. 2015;5:92.

4. Kim JK, Kim HJ, Chung JY, Lee JH, Young SB, Kim YH. Natural and synthetic biomaterials for controlled drug delivery. Arch Pharm Res. 2014;37(1):60-68.

5. Johnson TD, Christman KL. Injectable hydrogel therapies and their delivery strategies for treating myocardial infarction. Expert Opin Drug Deliv. 2013;10(1):59-72.

6. Zhang S, Holmes T, Lockshin C, et al. Spontaneous assembly of a selfcomplementary oligopeptide to form a stable macroscopic membrane. Proc Natl Acad Sci U S A. 1993;90(8):3334-3338.

7. Nagai Y, Unsworth LD, Koutsopoulos S, Zhang S. Slow release of molecules in self-assembling peptide nanofiber scaffold. $J$ Control Release. 2006;115(1):18-25.

8. Liu J, Liu S, Chen Y, Zhao X, Lu Y, Cheng J. Functionalized selfassembling peptide improves INS-1 $\beta$-cell function and proliferation via the integrin/FAK/ERK/cyclin pathway. Int J Nanomedicine. 2015;10: 3519-3531.

9. Gelain F, Unsworth LD, Zhang S. Slow and sustained release of active cytokines from self-assembling peptide scaffolds. J Control Release. 2010;145(3):231-239.
10. Luo Z, Yue Y, Zhang Y, et al. Designer D-form self-assembling peptide nanofiber scaffolds for 3-dimensional cell cultures. Biomaterials. 2013;34(21):4902-4913.

11. Nishimura A, Hayakawa T, Yamamoto Y, et al. Controlled release of insulin from self-assembling nanofiber hydrogel, PuraMatrix ${ }^{\mathrm{TM}}$ application for the subcutaneous injection in rats. Eur J Pharm Sci. 2012;45(1-2):1-7.

12. Liu J, Zhang L, Yang Z, Zhao X. Controlled release of paclitaxel from a self-assembling peptide hydrogel formed in situ and antitumor study in vitro. Int J Nanomedicine. 2011;6:2143-2153.

13. Ogawa $T$, Akazawa $T$, Tabata $Y$. In vitro proliferation and chondrogenic differentiation of rat bone marrow stem cells cultured with gelatin hydrogel microspheres for TGF- $\beta 1$ release. J Biomater Sci. 2010;21(5): 609-621.

14. Kopesky PW, Byun S, Vanderploeg EJ, Kisiday JD, Frisbie DD, Grodzinsky AJ. Sustained delivery of bioactive TGF- $\beta 1$ from self-assembling peptide hydrogels induces chondrogenesis of encapsulated bone marrow stromal cells. J Biomed Mater Res A. 2014;102(5): $1275-1285$.

15. Solorio LD, Vieregge EL, Dhami CD, Dang PN, Alsberg E. Engineered cartilage via self-assembled hMSC sheets with incorporated biodegradable gelatin microspheres releasing transforming growth factor- $\beta 1$. $J$ Control Release. 2012;158(2):224-232.

16. Luo Z, Wang S, Zhang S. Fabrication of self-assembling d-form peptide nanofiber scaffold d-EAK16 for rapid hemostasis. Biomaterials. 2011;32(8):2013-2020.

17. Luder K, Kulkarni K, Lee HW, et al. Decorated self-assembling $\beta 3$-tripeptide foldamers form cell adhesive scaffolds. Chem Commum. 2016;52(24):4549-4552.

18. Castells-Sala C, Recha-Sancho L, Llucià-Valldeperas A, SolerBotija C, Bayes-Genis A, Semino CE. Three-dimensional cultures of human subcutaneous adipose tissue-derived progenitor cells based on RAD16-I self-assembling peptide. Tissue Eng Part C Methods. 2016; 22(2):113-124.

19. Kisiday JD, Kopesky PW, Evans CH, Grodzinsky AJ, Mcllwraith CW, Frisbie DD. Evaluation of adult equine bone marrow- and adiposederived progenitor cell chondrogenesis in hydrogel cultures. J Orthop Res. 2008;26(3):322-331.

20. Chen G, Deng C, Li YP. TGF- $\beta$ and BMP signaling in osteoblast differentiation and bone formation. Int J Biol Sci. 2012;8(2):272-288.

21. Huang JI, Kazmi N, Durbhakula MM, Hering TM, Yoo JU, Johnstone B. Chondrogenic potential of progenitor cells derived from human bone marrow and adipose tissue: a patient-matched comparison. J Orthop Res. 2005;23(6):1383-1389.

22. Koutsopoulos S, Unsworth LD, Nagai Y, Zhang S. Controlled release of functional proteins through designer self-assembling peptide nanofiber hydrogel scaffold. Proc Natl Acad Sci U S A. 2009;106(12): 4623-4628.

23. Bae H, Chu H, Edalat F, et al. Development of functional biomaterials with micro- and nanoscale technologies for tissue engineering and drug delivery applications. J Tissue Eng Regen Med. 2014;8(1):1-14.

24. Hsieh PC, Davis ME, Gannon J, MacGillivray C, Lee RT. Controlled delivery of PDGF-BB for myocardial protection using injectable selfassembling peptide nanofibers. J Clin Invest. 2006;116(1):237-248.

25. McCarthy HO, McCaffrey J, McCrudden CM, et al. Development and characterization of self-assembling nanoparticles using a bio-inspired amphipathic peptide for gene delivery. J Control Release. 2014;189: 141-149.

26. Kumar VA, Taylor NL, Shi S, Wickremasinghe NC, D'Souza RN, Hartgerink JD. Self-assembling multidomain peptides tailor biological responses through biphasic release. Biomaterials. 2015;52:71-78.

27. Luo Z, Zhao X, Zhang S. Self-organization of a chiral D-EAK16 designer peptide into a 3D nanofiber scaffold. Macromol Biosci. 2008; 8(8):785-791.

28. Shin YC, Lee JH, Jin L, et al. Cell-adhesive matrices composed of RGD peptide-displaying M13 bacteriophage/poly(lactic-co-glycolic acid) nanofibers beneficial to myoblast differentiation. $J$ Nanosci Nanotechnol. 2015;15(10):7907-7912. 
29. Shin YC, Lee JH, Kim MJ, et al. Biomimetic hybrid nanofiber sheets composed of RGD peptide-decorated PLGA as cell-adhesive substrates J Funct Biomater. 2015;6(2):367-378.

30. Sun Y, Li W, Wu X, et al. Functional self-assembling peptide nanofiber hydrogels designed for nerve degeneration. ACS Appl Mater Interfaces. 2016;8(3):2348-2359.
31. Cohen K, Flint N, Shalev S, et al. Thyroid hormone regulates adhesion, migration and matrix metalloproteinase 9 activity via $\alpha v \beta 3$ integrin in myeloma cells. Oncotarget. 2014;5(15):6312-6322.

32. He B, Ou YS, Zhou A, et al. Functionalized d-form self-assembling peptide hydrogels for bone regeneration. Drug Des Devel Ther. 2016;10: 1379-1388.

\section{Publish your work in this journal}

Drug Design, Development and Therapy is an international, peerreviewed open-access journal that spans the spectrum of drug design and development through to clinical applications. Clinical outcomes, patient safety, and programs for the development and effective, safe, and sustained use of medicines are the features of the journal, which has also been accepted for indexing on PubMed Central. The manuscript management system is completely online and includes a very quick and fair peer-review system, which is all easy to use. Visit http://www.dovepress.com/testimonials.php to read real quotes from published authors.

Submit your manuscript here: http://www.dovepress.com/drug-design-development-and-therapy-journal 